\title{
KORELASI PENGGUNAAN STRATEGI KOGNITIF DENGAN KEMAMPUAN MENULIS PENGALAMAN PRIBADI SISWA KELAS VIII MTS. SYAMSUL HUDA PERESAK, DESA SEPAKEK, KECAMATAN PRINGGARATA, KABUPATEN LOMBOK TENGAH
}

\author{
Arpan Islami Bilal \\ Program Studi Pendidikan Bahasa dan Sastra Indonesia \\ FKIP Universitas Muhammadiyah Mataram \\ islami_bilal@yahoo.com
}

\begin{abstract}
Abstrak
Tujuan dari penelitian ini adalah untuk mendeskripsikan penggunaan strategi kognitif siswa kelas VIII MTs. Syamsul Huda Peresak, Desa Sepakek, Kecamatan Pringgarata, Kabupaten Lombok Tengah, mendeskripsikan kemampuan menulis pengalaman pribadi siswa kelas VIII MTs. Syamsul Huda Peresak, Desa Sepakek, Kecamatan Pringgarata, Kabupaten Lombok Tengah dan mendeskripsikan korelasi/hubungan penggunaan strategi kognitif dan kemampuan menulis pengalaman pribadi siswa kelas VIII MTs. Syamsul Huda Peresak, Desa Sepakek, Kecamatan Pringgarata, Kabupaten Lombok Tengah.

Pendekatan yang digunakan dalam penelitian ini adalah pendekatan kuantitatif korelasional. Dengan jumlah sampel 31 Mahasiswa yang terdiri 18 laki-laki dan 13 perempuan. Kegiatan pengumpulan data dilakukan dengan menggunakan (1) angket berupa pertanyaan untuk mengetahui strategi kognitif yang digunakan siswa dalam menulis. (2) tes kemampuan menulis pengalaman pribadi.

Dari hasil korelasi koefisien dengan program SPSS 14.00 proses analisis data tentang korelasi/hubungan penggunaan strategi kognitif dengan kemampuan menulis pengalaman pribadi siswa kelas VIII MTs. Syamsul Huda Peresak, Desa Sepakek, Kecamatan Pringgarata, Kabupaten Lombok Tengah dengan menggunakan rumus koefisien korelasi product moment diperoleh nilai $r_{x y}=0,532$. Nilai $r_{\text {hitung }}$ tersebut kemudian dikonsultasikan pada tabel $r$ Product Moment pada $\mathrm{N}=31$ dengan taraf signifikan $1 \%(\alpha=0,01)$ dan diperoleh nilai $\mathrm{r}_{\text {tabel }}=0,456$. Karena nilai $r_{\text {hitung }}$ lebih besar dari nilai $r_{\text {tabel }}$, maka dapat disimpulkan bahwa hipotesis nol $\left(\mathrm{H}_{0}\right)$ ditolak dan hipotesis kerja $\left(\mathrm{H}_{1}\right)$ dapat diterima.
\end{abstract}

Kata kunci : Strategi kognitif, menulis pengalaman pribadi.

\section{PENDAHULUAN}

Menulis adalah salah satu cara berbicara secara tidak langsung untuk mengungkapkan gagasan, perasaan, pikiran dan kemauan kepada orang lain secara tertulis. Melalui proses menulis seseorang dapat mengungkapkan gagasan, perasaan, pikiran atau pendapatnya sesuai denga keinginannya. Hasil kegiatan menulis ini akan menghasilkan suatu karya tulis, dan apabila karya tulis itu dapat dibaca dan dipahami oleh pembacanya, maka gagasan, pikiran, perasaan, atau pendapat penulis telah mencapai maksud dan tujuan menulis. 
Sebelum memulai menulis, hal pertama yang akan dilakukan siswa adalah memikirkan topik apa yang akan mereka rangkai menjadi tulisan. Jika dirasa sudah menemukan beberapa topik yang akan diambil untuk dijadikan tulisan maka siswa tersebut akan memutuskan untuk mengambil satu topik. Setelah menemukan topik siswa akan mulai bernalar untuk mengembangkan isi dalam tulisannya. Karena itulah dalam kesempatan ini peneliti ingin membahas tentang strategi kognitif yang erat kaitannya dengan kemampuan menulis siswa.

Menurut Oxford (1990:11) Ada tiga ragam strategi kognitif yang biasa digunakan untuk pembelajaran menulis siswa, yaitu: mempraktekkan, analisis dan penalaran, dan menciptakan struktur untuk input dan output. Di mana strategi mempraktekkan berisi lima strategi: mengulang, berlatih tulisan secara formal, menggunakan rumusan dan pola, menggabungkan ulang, dan mempraktekkan secara alami. Analisis dan penalaran meliputi menterjemah dan mentransfer. Menciptakan struktur untuk input dan output berisi tiga strategi: membuat catatan, membuat ringkasan dan menyoroti.

Peneliti memilih judul korelasi penggunaan strategi kognitif dengan kemampuan menulis pengalaman pribadi siswa MTs. Syamsul Huda Peresak dalam kegiatan menulis pengalaman pribadi. Untuk mengetahui apakah siswa menggunakan strategi kognitif pada keterampilan menulisnya. Penelitian ini dilakukan pada siswa MTs. Syamsul Huda Peresak kelas VIII pada saat mengikuti pembelajaran bahasa \& sastra Indonesia.

\section{Rumusan Masalah}

Berdasarkan latar belakang di atas maka rumusan masalah dalam penelitian ini di bagi menjadi dua yaitu:

1. Bagaimanakah strategi kognitif yang digunakan dalam belajar menulis pengalaman pribadi siswa kelas VIII MTs. Syamsul Huda Peresak, Desa Sepakek, Kecamatan Pringgarata, Kabupaten Lombok Tengah?,

2. Bagaimanakah kemampuan menulis pengalaman pribadi siswa kelas VIII MTs. Syamsul Huda Peresak, Desa Sepakek, Kecamatan Pringgarata, Kabupaten Lombok Tengah?, dan

3. Bagaimanakah korelasi penggunaan strategi kognitif dengan kemampuan menulis pengalaman pribadi siswa kelas VIII MTs. Syamsul Huda Peresak, Desa Sepakek, Kecamatan Pringgarata, Kabupaten Lombok Tengah?. 


\section{Tujuan Penelitian}

1. Untuk memperoleh deskripsi objektif tentang strategi kognitif yang digunakan dalam belajar menulis pengalaman pribadi siswa kelas VIII MTs. Syamsul Huda Peresak, Desa Sepakek, Kecamatan Pringgarata, Kabupaten Lombok Tengah,

2. Untuk memperoleh deskripsi objektif tentang kemampuan menulis pengalaman pribadi siswa kelas VIII MTs. Syamsul Huda Peresak, Desa Sepakek, Kecamatan Pringgarata, Kabupaten Lombok Tengah, dan

3. Untuk membuktikan apakah ada korelasi/hubungan penggunaan strategi kognitif dengan kemampuan menulis pengalaman pribadi siswa kelas VIII MTs. Syamsul Huda Peresak, Desa Sepakek, Kecamatan Pringgarata, Kabupaten Lombok Tengah.

\section{METODE PENELITIAN}

\section{Rancangan Penelitian}

Penelitian merupakan usaha untuk menemukan, mengem-bangkan, dan melakukan verifikasi (pemeriksaan tentang benar atau tidak) terhadap suatu peristiwa atau suatu pengetahuan dengan mempergunakan metode-metode ilmiah.
Metode adalah cara kerja yang bersistem untuk mempermudah pelaksanan suatu kegiatan guna mencapai tujuan yang ditentukan (Kamus Besar Bahasa Indonesia, 2007:740). Sedangkan Surachmad (1994:121) berpendapat bahwa metode merupakan cara utama yang dipergunakan untuk mencapai suatu tujuan, misalnya untuk menguji serangkaian hipotesa, dengan menggunakan teknik serta alat-alat tertentu. Cara utama itu dipergunakan setelah penyelidikan serta dari situasi penyelidikan.

Penelitian adalah kegiatan pengumpulan, pengolahan, analisis, dan penyajian data yang dilakukan secara sistematis dan objektif untuk memecahkan suatu persoalan atau menguji suatu hipotesis untuk mengembangkan prisipprinsip umum (Kamus Besar Bahasa Indonesia, 2007:849).

Penelitian ini menggunakan pendekatan kuantitatif korelasional. Dimana penelitian kuantitatif korelasional yaitu penelitian yang bertujuan untuk mengukur tingkat hubungan dua variabel atau lebih, namun tidak megidentifikasi tentang hubungan sebab akibat. Dalam penelitian ini menggunakan dua variabel yaitu strategi kognitif sebagai independent variabel, kemampuan menulis pengalaman pribadi sebagai dependent variabel. 


\section{Populasi dan Sampel Penelitian}

Populasi penelitian

Populasi adalah keseluruhan dari subjek penelitian (Arikunto, 1993:115). Sedangkan Komarudin (1987:203) menyatakan bahwa populasi adalah sekumpulan kasus yang memenuhi syaratsyarat tertentu yang berkaitan dengan masalah penelitian. Kasus-kasus tersebut berupa orang, barang, binatang, hal, atau peristiwa.

Mendasar pada uraian diatas maka yang menjadi populasi penelitian ini adalah seluruh siswa kelas VIII MTs. Syamsul Huda Peresak, Desa Sepakek, Kecamatan Pringgarata, Kabupaten Lombok Tengah sejumlah 30 siswa . Yang berjenis kelamin laki-laki berjumlah 18 anak dan perempuan berjumlah 12 siswa.

Sampel penelitian

Sampel adalah sebagian atau wakil populasi yang diteliti (Arikunto, 1998:104). Tujuan penentuan sampel menurut Komaruddin dapat dijelaskan sebagai berikut:

1. Untuk memperoleh keterangan mengenai objek penyelidikan dengan cara menganati hanya sebagian dari populasi, suatu reduksi terhadap jumlah objek penyelidikan,
2. Untuk mengemukakan dengan tepat sifat-sifat umum dari populasi dan untuk menarik generalisasi dari hasil penyelidikan, dan

3. Untuk mengadakan penaksiran peramalan dan pengujian hipotesis yang telah dirumuskan.

$$
\text { Menurut Arikunto }
$$

menjelaskan bahwa apabila jumlah sampel kurang dari 100 orang, maka sebaiknya sample diambil secara keseluruhan, tetapi apabila jumlah sampel lebih dari 100 orang maka pengambilan sampel sebanyak 10-15 persen atau 20-25 persen saja.

Jumlah siswa kelas VIII MTs. Syamsul Huda Peresak, Desa Sepakek, Kecamatan Pringgarata, Kabupaten Lombok Tengah sebanyak 30 siswa. Dengan demikian dari 30 siswa kelas VIII MTs. Syamsul Huda Peresak, Desa Sepakek, Kecamatan Pringgarata, Kabupaten Lombok Tengah diambil keseluruhannya sebagai sampel pada penelitian ini.

\section{Instrumen Penelitian}

$$
\begin{aligned}
& \text { Instrument adalah alat yang } \\
& \text { digunakan untuk mengumpulkan data. } \\
& \text { Untuk menjaring data maka dapat } \\
& \text { digunakan } 2 \text { macam instrument, instrument } \\
& \text { tersebut berkedudukan sebagai pengumpul } \\
& \text { istrumen korelasi antara penggunaan } \\
& \text { strategi kognitif dan kemampuan menulis }
\end{aligned}
$$


pengalaman pribadi siswa kelas VIII MTs. Syamsul Huda Peresak, Desa Sepakek, Kecamatan Pringgarata, Kabupaten Lombok Tengah. Instrument penelitiannya berupa (1) angket, (2) tes.

\section{Teknik Analisis Data Penelitian}

Menurut Arikunto (1991:191) secara garis besar pekerjaan analisis data meliputi tiga langkah yaitu: 1) Persiapan, 2) tabulasi, dan 3) penerapan data sesuai dengan pendekatan penelitian.

\section{Analisis Data}

Dalam penelitian ini digunakan metode analisis kuantitatif dengan rumus Koefisien Korelasi Product Moment:

$$
\begin{aligned}
& r_{x y} \frac{N \sum X Y-\left(\sum X\right)\left(\sum Y\right)}{\sqrt{\left[N \sum X^{2}-\left(\sum X\right)^{2}\left[N \sum Y^{2}-\left(\sum Y\right)^{2}\right]\right.}} \\
& \text { (Arikunto, 1991:136) } \\
& \mathrm{r}_{\mathrm{xy}} \quad=\text { Koefisien korelasi antara } \\
& \text { variabel x dan y } \\
& N \quad=\text { Jumlah sampel } \\
& \sum X \quad=\text { Skor Strategi kognitif. } \\
& \sum Y \quad=\quad \text { Nilai Kemampuan }
\end{aligned}
$$$$
\text { menulis pengalaman pribadi }
$$$$
\sum X Y=\text { jumlah perkalian } \mathrm{X} \text { dan } \mathrm{Y}
$$$$
\sum \mathrm{X}^{2}=\text { Jumlah Kuadrat } \mathrm{X}
$$$$
\sum \mathrm{Y}^{2}=\text { Jumlah kuadrat } \mathrm{Y}
$$

\section{HASIL PENELITIAN DAN} PEMBAHASAN

\section{Hasil Analisis Data}

Pada bagian ini dikemukakan (1) hasil strategi kognitif, (2) hasil tes menulis pengalaman pribadi dan (3) korelasi penggunaan strategi kognitif dan kemampuan menulis pengalaman pribadi. Akan dibahas sebagai berikut:

1. Hasil strategi kognitif

Penyebaran angket dilakukan pada saat siswa sedang dalam proses belajar mengajar bahasa indonesia. Dan nilai penggunaan strategi belajar yang didapat dari angket sebagai data variabel $(\mathrm{X})$ adalah diperolehnya nilai tertinggi 76 , nilai terendah 48 dan nilai rata-rata 66.

Penggunaan strategi kognitif siswa kelas VIII MTs. Syamsul Huda Peresak, Desa Sepakek, Kecamatan Pringgarata, Kabupaten Lombok Tengah termasuk kategori cukup. Hal ini dibuktikan dengan sebanyak 0\% siswa yang dikategorikan sangat tinggi, $39 \%$ siswa dikategorikan tinggi, 32\% siswa dikategorikan cukup, 26\% siswa dikategorikan rendah, dan 3\% siswa dikategorikan sangat rendah.

2. Hasil tes menulis pengalaman pribadi

Berdasarkan nilai hasil tes menulis pengalaman pribadi yang diberikan oleh peneliti pada saat prosess pembelajaran bahasa indonesia kepada siswa kelas VIII MTs. Syamsul Huda Peresak, Desa Sepakek, Kecamatan Pringgarata, Kabupaten Lombok Tengah yang 
berjumlah 31 siswa, yaitu 18 siswa lakilaki dan 13 siswa perempuan. Data nilai hasil kemampuan menulis yang didapat dari tes menulis pengalaman pribadi sebagai variabel (Y) adalah diperoleh nilai rata-rata 60 , dengan nilai tertinggi 80 dan nilai terendah 60 .

Kemampuan menulis pengalaman pribadi siswa kelas VIII MTs. Syamsul Huda Peresak, Desa Sepakek, Kecamatan Pringgarata, Kabupaten Lombok Tengah termasuk kategori baik. Hal ini dibuktikan dengan sebanyak 3\% siswa dikategorikan sangat baik, $71 \%$ siswa dalam kategori baik, 26\% siswa dalam kategori cukup, $0 \%$ siswa dalam ketegori rendah dan $0 \%$ siswa dalam kategori sangat rendah.

3. Korelasi penggunaan strategi kognitif dan kemampuan menulis pengalaman pribadi

Uji koefisien korelasi product moment ini akan memberikan gambaran ada atau tidaknya korelasi/hubungan yang signifikan dalam penggunaan strategi kognitif dengan kemampuan menulis pengalaman pribadi siswa kelas VIII MTs. Syamsul Huda Peresak, Desa Sepakek, Kecamatan Pringgarata, Kabupaten Lombok Tengah, dalam meganalisis data peneliti menggunakan program SPSS 14.
Proses analisis data tentang korelasi/hubungan penggunaan strategi kognitif dengan kemampuan menulis pengalaman pribadi siswa kelas VIII MTs. Syamsul Huda Peresak, Desa Sepakek, Kecamatan Pringgarata, Kabupaten Lombok Tengah dengan menggunakan rumus koefisien korelasi product moment diperoleh nilai $\mathrm{r}_{\mathrm{xy}}=$ 0,532 .

\section{DAFTAR RUJUKAN}

Arikunto, Suharsimi. 1991. Prosedur Penelitian. Jakarta: Bina Aksara.

Arikunto, Suharsimi. 1998. Prosedur Penelitian. Jakarta: Bina Aksara.

Departemen Pendidikan Nasional. 2007. Kamus Besar Bahasa Indonesia. Jakarta: Balai Pustaka.

Gilangsari, Yuni. 2005. Peningkatan Keterampilan Menulis Pengalaman Pribadi Melalui Teknik Modeling Dengan Pendekatan Kontekstual pada Siswa kelas VIID SMP Negeri 38 Semarang Tahun Ajaran 2004/2005. (Online), (http;//www.google.com. diakses 4 januari 2011).

Ikatan Sarjana Teknologi Pendidikan Indonesia. 2008. Peran Strategi Kognitif dalam Akselerasi pembelajaran. (online). (http;//istpi.wordpress.com/2008/0 6/19/peran-strategi-kognitif-dalamakselerasi-pembelajaran.html, diakses 5 januari 2011). 
Karmila. 2009. Hubungan antara strategi belajar membaca dan kemampuan membaca pemahaman mahasiswa Pendidikan bahasa dan sastra indonesia fkip unisma Tahun 2009/2009. Skripsi tidak diterbitkan. Malang: Program sarjana UNISMA.

Keraf, Gorys. 2000. Argumentasi dan Narasi. Jakarta: Gramedia Pustaka Utama.

Komaruddin. 1987. Kamus Riset. Bandung: Angkasa.

Nasional, Departemen Pendidikan. 2007. Kamus Besar Bahasa Indonesia. Edisi Ketiga. Jakarta: Balai pustaka.

Oxford, Rebecca L.1990. Languege Learning Strategies. New York: Universitas Alabama.

Prasetyoningsih, Luluk Sri Agus. 2001. Menulis II. Malang: UNISMA

Surachmad, Winarno. 1994. Dasar dan Teknik Reseach Pengantar Metodologi Ilmiah. Bandung: Tarsito.

Tarigan, Henry Guntur. 1994. Menulis Sebagai Suatu Keterampilan Berbahasa. Bandung: Angkasa.

Wahyuni, Sri. 2005. Evaluasi

Pembelajaran Bahasa Indonesia. Malang: UNISMA. 
Jurnal Ilmiah Telaah Vol. 3 No. 1, Januari 2018 